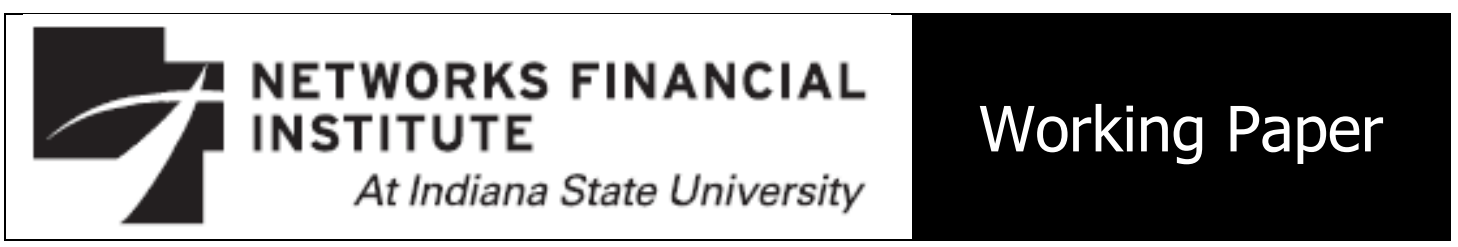

2014-WP-01

March 2014

\title{
Partial Adjustment Toward Equilibrium Mutual Fund Allocations: Evidence from U.S.-based Equity Mutual Funds
}

\section{Kabir Hassan and William J. Hippler III}

Abstract: Mutual fund managers face increasing competition and have incentives to quickly reallocate their portfolios in order to achieve the best risk-adjusted return. However, portfolio allocation is costly, as trading, administrative, and information costs all lower returns after management fees. Therefore, the mutual fund manager's portfolio allocation decision is one of a tradeoff between the benefits of quick portfolio adjustment and the associated costs of adjustment. We apply an asymmetric partial adjustment model to a sample of U.S. equity mutual funds from 2000 through 2012. Empirical results shows that mutual fund managers are able and willing to quickly adjust portfolios when the fund underperforms, offsetting nearly 95 percent of the deviation within one month, indicating that managers perceive the costs of retaining sub-optimal portfolios to be high, relative to the costs of rebalancing. The results are consistent across different types of equity funds. As a secondary result, we show that the speed of adjustment is fairly stable over the 2000 to 2012 sample period, but does exhibit some cyclicality. The application of the partial adjustment model methodology to the mutual fund literature is novel and contributes significantly to the current literature. In addition, the preliminary results have important implications as to the efficiency of mutual funds, which has been questioned in recent years and is relevant to mutual fund investors, managers, and governors.

About the Authors: Kabir Hassan is a professor at the University of New Orleans. He is a financial economist with consulting, research and teaching experiences in development finance, money and capital markets, corporate finance, investments, monetary economics, macroeconomics and international trade and finance. He has published five books, over 135 articles in refereed academic journals and has presented over 255 research papers at professional conferences globally.

William Hippler is a Ph.D. student in the field of Financial Economics with the Department of Economics and Finance at the University of New Orleans where he is currently teaching for the Department of Economics and Finance. His areas of interest are financial markets and institutions, international diversification, portfolio management, and corporate finance.

Keywords: Mutual Funds, Partial Adjustment Models, Active Portfolio Management, Mutual Fund Performance and Efficiency

JEL classification: C23, G14, G20

The views expressed are those of the individual author and do not necessarily reflect official positions of Networks Financial Institute. Please address questions regarding content to Kabir Hassan at mhassan@uno.edu. Any errors or omissions are the responsibility of the author.

NFI working papers and other publications are available on NFI's website (www.networksfinancialinstitute.org). Click "Research" and then "Publications/Papers." 


\section{Introduction}

The development and implementation of mutual funds and other pooling arrangements has been a major trend in the financial markets for several decades. The economies of scale present in these arrangements lower the costs of diversification for smaller investors. Additionally, arrangements like mutual funds can provide lay investors with cheaper access to professional, active portfolio management. As a consequence, smaller investors have become more active in the financial markets through retirement and other investment accounts that utilize mutual funds as a main conduit for low-cost diversification.

The cost efficiencies and active management benefits of mutual funds come at a cost, however. For example, there remains significant debate as to whether actively managed mutual funds actually outperform the overall market index on a risk-adjusted basis after management fees are deducted. For this reason, more passive pooling arrangements have been developed to answer the concern that active management provides very little additional risk-adjusted return. Index and sector-mimicking funds, for example, allow smaller investors to reap the benefits of low-cost diversification, while taking a more passive market stance, thus lowering the management fees associated with active management.

With the development of different types of pooling arrangements, it is important for investors to know which types of funds are most efficient. While passive funds may be more cost efficient, it is possible that more actively managed funds can more efficiently rebalance their portfolios due to the informational advantages captured by active managers. While the literature in the area of mutual funds has often focused on the efficiency of funds in terms of return efficiency, there is currently no evidence showing the time dimension of mutual fund efficiency. Specifically, the literature lacks empirical evidence regarding how quickly different types of 
mutual funds are able to adjust their portfolios to the equilibrium return. This dimension of efficiency is an important issue that has been left largely unaddressed, since longer adjustment times may represent additional fund risk that has previously been left unquantified.

Mutual fund managers are charged with selecting a portfolio of securities consistent with the fund's objective in order to maximize the investor's risk-adjusted return. The fund managers make these selections based on a set of publicly available information. It is safe to assume that portfolio managers are rational and thus have correct market expectations, given their information set. However, the set of information available to managers may be limited by the characteristics of the fund. It is reasonable to assume that funds focusing on one sector of the economy and charging relatively high management fees are able to extract more or better information than managers that are limited to more passive management. Thus, the relatively higher exposure to systematic risk may be offset by more efficient management of information as evidenced by faster portfolio adjustment.

In this paper, we apply a partial adjustment econometric estimation procedure to the CRSP mutual fund database in order to analyze how quickly mutual funds adjust to measures of the equilibrium risk-adjusted return. In section 6 , we apply the model to the full sample of mutual funds, and find that underperforming funds adjust relatively quickly to deviations in measures of risk-adjusted return, which is consistent with the idea that managers face significant costs for underperformance. Then, in section 7, we apply the model to eight sub-samples of funds based on their investment focus. We show that the speed of adjustment is heterogeneous across different types of funds, consistent with the idea that managers of different types of funds have heterogeneous information costs. In section 8 , we show how the speed of adjustment for mutual funds appears to be consistent over time, but does exhibit some cyclicality consistent 
with changes in the information efficiency of the markets. Section 9 discusses robustness issues as well as areas in which we hope to expand the paper. Section 10 concludes.

\section{Previous Empirical Findings}

The previous empirical literature on mutual fund performance and management show a wide range of often-conflicting results. While some studies find that active mutual fund managers are able to provide abnormal returns to investors, others find that, net of the expenses charged for active management, mutual funds actually underperform passively managed indexes. Other studies find that the abnormal returns earned by mutual fund managers are essentially offset by management fees, essentially leaving investors with a net return equivalent to those of passively managed pooling arrangements. The performance of highly active equity mutual funds, relative to that of more passive funds, has important implications as to the informational efficiency of the stock market. Severe underperformance of mutual funds implies that investors are either irrational, because they fail to take advantage of better performing assets, or misinformed in that they are unaware that they are achieving suboptimal returns. Consistent positive abnormal performance, on the other hand, implies that mutual fund managers have superior information and pass that advantage to investors in the form of higher returns. As arbitrage occurs and the mutual fund market matures, it may be expected that both fund managers and investors become increasingly competitive and the aggregate equilibrium net returns for actively managed mutual funds equal those of alternative investments, such as index funds.

The seminal work of Sharpe (1966) pioneered the use of empirical techniques to evaluate mutual fund performance. Among other contributions, Sharpe developed a measure of mutual 
fund performance that evaluates return, relative to the risk undertaken. The theoretical motivation for developing a risk-adjusted performance measure is to eliminate performance differences caused by fund idiosyncrasies such as investment style and risk tolerance. In an efficient market, one expects all funds to achieve the same risk-return tradeoff, as measured in this manner. However, the results of his study show that, even when using a measure that takes into consideration risk-adjusted returns, mutual fund performance differs among funds. The discrepancy in performance among mutual funds may be driven by differences in expenses and management fees, among other factors. The interesting results of Sharpe's research drive a line of literature dealing with mutual fund performance.

Among the earlier studies responding to evidence presented by Sharpe and others is Ippolito (1989), which examines the role of information costs in the context of U.S. mutual funds. In an empirical study using data from 143 mutual funds over the 1965 to 1984 time period, the study finds that the returns of mutual funds are commensurate with those of passive funds, or the overall market, even after considering information costs in the form of management fees and expenses. The results that show active management is worth its cost are consistent with market efficiency, because the fees charged by managers offset the cost of acquiring specialized information. Net of the fees charged for information acquisition and management, investors receive net returns that are equivalent to those of other available asset portfolios, such as index funds. In addition, Ippolito (1989) finds no relationship between management fees and turnover and fund performance.

Supporting the idea that active management provides value to investors, Daniel et al. (1997) examine the ability of equity mutual fund managers in terms of selection and timing abilities. The authors develop measures of performance based on fund characteristics, such as 
book-to-market, market capitalization, style, etc. They find that actively managed funds achieve performance advantages over passively managed funds; however, the magnitude of the advantage is small and roughly offset by management fees. For example, aggressive and momentum-based funds tend to have the highest performance advantages, but they also have higher associated management expenses.

There are also empirical studies that find active managers are able to achieve abnormal returns that are worth the increased expense, but that advantage is only realized by a minority of fund managers. For example, Kosowski et al. (2006) use a bootstrap methodology ${ }^{1}$ to analyze returns from U.S. open-ended funds from 1975 to 2002 . The bootstrap methodology is necessary to circumvent problems with non-normality of alphas in the distribution of mutual fund returns. ${ }^{2}$ In light of the bootstrap methodology, the authors find that there are some managers who are able to generate returns that offset the fees charged by managers. In addition, they find that the ability of some active mutual fund managers to achieve abnormal returns persists over time. ${ }^{3}$ In addition, Volkman (1999) investigates the performance of mutual funds in the context of increased market volatility and finds that active mutual funds in aggregate do not possess superior stock selection ability, but some managers are able to consistently select undervalued securities. However, even though some managers exhibit superior stock selection skill, their ability to time the market is often not optimal. ${ }^{4}$

\footnotetext{
${ }^{1}$ They argue that this methodology is necessary to eliminate biases due to non-normal distributions caused by ex post sorting on mutual fund performance.

${ }^{2}$ Other studies, such as Fama and French (2010) also advocate the use of bootstrapping methodologies in dealing with distribution issues.

${ }^{3}$ They find that this result holds mostly for managers of growth-oriented funds, but find no evidence that income-oriented funds achieve persistent abnormal returns.

${ }^{4}$ The results also suggest a negative relationship between management compensation and selection ability - a puzzling result. In addition, the results find that larger funds tend to have better stock selection ability.
} 
Barras et al. (2010) provide further evidence that mutual funds do not consistently provide abnormal returns in aggregate. They attribute previous findings that mutual funds experience persistent positive alpha as "false discoveries." In their methodology, they divide funds based on whether their managers are skilled or unskilled and find that 75 percent of funds do not exhibit positive alpha. In a related finding, they show that there were significantly more "skilled" funds in existence in 1996 than in $2006,{ }^{5}$ which supports the idea that increased competition and access to information has removed the ability of mutual fund managers to yield abnormal returns, net of expenses. They argue that although there is a minority of "skilled" managers who can achieve high returns, actively managed funds underperform (net of expenses) in aggregate due to the persistence of underperforming funds.

On the other hand, there is a growing line of literature that argues that results showing persistent positive abnormal returns for active managers are driven by specific biases and methodological issues that, when corrected, question the efficiency of actively managed mutual funds. In an early empirical study along this line, Lehmann and Modest (1987) examine 130 U.S. mutual funds from 1968 to 1982 . The empirical results indicate that estimates of mutual fund performance are sensitive to the pricing model and estimation method used to compute abnormal returns. The authors use various specifications of the CAPM and APT and different estimation techniques and find significantly different estimates of mutual fund abnormal performance. However, despite this fact, they still find that both CAPM and APT estimates show that mutual funds experience negative abnormal returns, which the authors find difficult to explain in an information efficient market. In addition, Kothari and Warner (2001) point to evidence suggesting that typical empirical tests of mutual fund performance are of low power. They use

\footnotetext{
${ }^{5}$ They also cite that this trend makes identification of the skilled funds more accurate in later years.
} 
simulated funds that mimic the behavior of actual funds, and the results show that typical empirical tests are very weak in detecting skill-based abnormal portfolio returns, especially when the characteristics of funds differ greatly from the market portfolio. As an alternative, the authors suggest that the power of tests can be improved by conducting event studies on mutual fund trading behavior. ${ }^{6}$

Further evidence by Elton et al. (1993) show that early evidence claiming the persistence of mutual fund abnormal performance was primarily driven by the portfolio used in deriving the abnormal performance measures. The authors use a sample spanning 1965 to 1984 to show that estimated risk-adjusted measures of performance for mutual funds imply that mutual funds are not efficient enough to justify their expenses. The authors attribute most of the cost to information costs associated with actively managed funds and conclude that previous literature implying positive alphas or abnormal returns is due to the exclusion of non-S\&P assets in the calculation of performance evaluation measures. They find that accounting for these assets shows that actively managed funds underperform more mechanical or passive funds, and funds with high fees and turnover underperform those with low fees and turnover. These results imply that actively managed funds are inefficient.

Additional evidence by Wermers (2000) evaluates the ability of managers to select stocks that outperform enough to cover costs. Their results show that while managers tend to select stocks that outperform the market index by over one percentage point per year, the net returns underperform by roughly one percentage point per year. The authors attribute the majority of this discrepancy to expenses and transaction costs. However, they show that high turnover funds tend

\footnotetext{
${ }^{6}$ This study focuses on the ability to identify whether a particular fund is able to achieve abnormal returns.
} 
to perform well, which suggests that active management may add some value to investors. They also draw attention to the negative impact on mutual fund performance of cash and bond holdings that must be maintained to account for the uncertain cash flows into and out of the fund. Bollen and Busse (2005) examine the ability of managers to attain persistent abnormal returns by sorting mutual funds in percentiles based on performance and find that the highest percentile performance funds are unable to maintain high levels of abnormal performance over time.

In a more recent study, Fama and French (2010) concur with many previous studies that actively managed mutual funds rarely have abnormal returns high enough to overcome their significantly higher expenses. As a result, the real returns to mutual fund investors tend to be below those that are expected from the market portfolio. The authors use CRSP Data from 1984 to 2006 and a bootstrap methodology to differentiate skill from luck in the cross section of mutual fund returns. Consistent with earlier findings, the results show that a small percentage of managers appear to outperform the market, but that their good performance is offset in the cross section by those that do not meet performance expectations, net of cost. In addition, they find evidence that even the top performing active funds do not seem to outperform efficiently managed passive funds.

There is also a line of empirical literature that relates the manager characteristics of mutual funds to performance. In one such study, Sirri and Tufano (1998) analyze the flows into and out of mutual funds. They find that investors tend to funnel money into mutual funds with good prior performance. However, they document that this trend is asymmetric in that investors fail to flee lower performing funds. They find a significant relationship between expenses and fund inflows, which the authors attribute to more aggressive marketing efforts, which present as higher fees. In addition, funds that are part of a large fund family exhibit higher inflows as well. 
These results are consistent with the explanation that funds that achieve lower search costs for investors can realize significantly more cash inflows.

An empirical analysis that more directly ties manager characteristics with mutual fund performance is Chevalier and Ellison (1999). Chevalier and Ellison examine manager characteristics such as age, SAT score, and undergraduate institution and find that there is little relationship between fund performance and manager characteristics. However, there is a significant relationship between managers who attended high-SAT undergraduate institutions and mutual fund performance. ${ }^{7}$ They suggest this is due to either innate ability, better education, or better access to social networks. The results are consistent with a market having incomplete information and increased competition, whereby only slight advantages can be maintained. In a related study, Khorana (1996) shows that well performing funds are less likely to experience managerial turnover. ${ }^{8}$ This finding shows that managers have good reason to be concerned about relative performance, as deviation from optimal performance levels may result in their replacement.

Our study contributes to the mutual fund literature by applying a partial adjustment methodology to the mutual fund performance characteristics in an attempt to estimate the efficiency of mutual fund managers. Measuring the adjustment speed not only has important implications with regards to the efficiency of actively managed funds, but also provides insights into how fund managers weight the various costs associated with portfolio rebalancing. The insight gained from this analysis fills an important gap in the current literature.

\footnotetext{
${ }^{7}$ They also find that younger managers tend to make higher risk-adjusted returns than older managers. ${ }^{8}$ Managerial turnover is also found to be correlated with fund turnover, expenses, and overall portfolio risk.
} 


\section{The Model}

Mutual fund managers are charged with using the available information in the financial markets in order to maximize risk-adjusted return. Since the risk-adjusted return is based on economic fundamentals, there should exist an equilibrium or target level of risk-adjusted return. Thus, the mutual fund manager aims to achieve at least the equilibrium risk-adjusted return. The realized return of mutual funds should equal the equilibrium return over the long run. However, individual returns will deviate from the equilibrium due to both poor investment decisions and random price movements. When the fund returns are below those of other funds of equivalent risk, the managers will have an incentive to rebalance the portfolio with securities that will close the deviation from the equilibrium. However, portfolio rebalancing is costly. The costs of rebalancing include the search and information costs necessary to insure the selected securities will achieve the desired risk and return trade-off. Thus, the mutual fund manager faces a rebalancing decision where he or she must balance the benefits of retaining investors through a more efficient allocation with the costs of rebalancing.

The mutual fund manager's problem of balancing the costs and benefits of portfolio reallocation are consistent with a model of partial adjustment towards a target or equilibrium. Partial adjustment models can be applied in cases where there is a long-run equilibrium or optimal level for a variable of interest. Such models have been commonly applied to describe key relationships in economics and finance, such as the optimal level of leverage in a corporate finance context or the long-run equilibrium GDP growth of a country. Kennan (1979) describes the application of partial adjustment models to optimal behavior decisions in economic contexts and shows that, provided expectations are rational, the observed variables in question can be used in a partial adjustment model without having to directly observe the (unobservable) beliefs 
of the agents. As a result, the partial adjustment estimation will produce consistent estimates of the adjustment parameters. In the context of mutual fund performance, Cho and Shin (2011) develop a partial adjustment model based on a model whereby investors identify funds based on the past ability of managers to achieve returns and the assumption that there is partial adjustment in mutual fund portfolios. In the context of the paper, the authors show that a "smart money effect" exists for younger funds in Korea, because investors are uncertain as to the manager's ability. ${ }^{9}$

In a partial adjustment model, the economic relationship of interest can generalized as:

$$
y_{t}^{*}=\mu+\beta \boldsymbol{X}_{t}+\varepsilon_{t}
$$

In (1), $y_{t}^{*}$ is the equilibrium or optimal value of some variable of interest. In this study, we focus on the long-run, risk-adjusted returns of equity mutual funds, with such measures calculated using a Sharpe or Treynor ratio, or expected returns from an asset-pricing model. The parameter $\mu$ is the long-run equilibrium measure of risk-adjusted return, and $\boldsymbol{X}_{t}$ is a vector of variables that affect the long-run equilibrium return. Factors influencing the optimal riskadjusted return of a mutual fund include the risk-adjusted return of the market index and the riskadjusted return of a fund of a similar risk or style, among others.

Due to the costs of adjustment, mutual fund managers may choose to not continuously adjust their portfolios towards the equilibrium. Instead, the manager may choose to only attempt to offset some of the deviation. Thus, the change in the risk-adjusted return from one period to the next is given by:

\footnotetext{
${ }^{9}$ Consequently, the cash flow adjustment to and from these funds is higher, and these funds tend to outperform older funds. Additionally, the effect diminishes as funds age.
} 


$$
y_{t}-y_{t-1}=\lambda\left(y_{t}^{*}-y_{t-1}\right)
$$

The parameter $\lambda$ in (2) represents the proportion of the deviation from the optimum in one period that is reversed in the following period, or speed of adjustment. In the case of observed mutual fund returns, $\lambda$ will express both the amount of deviation that is offset due to purposeful manager portfolio rebalancing plus a component that is due to random variation.

In order to model the partial adjustment that mutual fund managers undergo in rebalancing portfolios, we can plug (1) into (2), rearrange, and simplify, to yield:

$$
y_{t}=\lambda \mu+\lambda \beta \boldsymbol{X}_{t}+(1-\lambda) y_{t-1}+\lambda \varepsilon_{t}
$$

The parameters in Equation (3) can be estimated using the regression model:

$$
y_{t}=\alpha+\theta \boldsymbol{X}_{t}+\gamma y_{t-1}+v_{t}
$$

The estimation of (4) will yield the parameter estimate $\hat{\gamma}$, which can be used to estimate $\hat{\lambda}$ as $\hat{\lambda}=1-\hat{\gamma}$, where $\hat{\lambda}$ describes the percentage deviation from the optimal or target riskadjusted return that is offset in one period. If there is partial adjustment towards a target, $\hat{\lambda}$ is bounded between 0 and 1 . The other parameters of interest can be estimated similarly as, $\hat{\beta}=\frac{\widehat{\theta}}{(1-\widehat{\gamma})}$ and $\hat{\mu}=\frac{\widehat{\alpha}}{(1-\widehat{\gamma})}$.

In the above representation $\hat{\lambda}$ is assumed to be equal whether adjustment is taking place from either below or above the target or equilibrium. However, this is not likely to apply in the case of mutual fund portfolio rebalancing. A mutual fund manager who achieves a return below 
the target has a great deal of incentive to rebalance toward the optimum. This has become increasingly true over time, as competition among mutual funds has increased and investors realizing sub-optimal returns will abandon their funds for more successful funds or other pooling arrangements. Conversely, a mutual fund manager who achieves a return above the target equilibrium (whether through superior security selection or luck) likely has much less incentive to expend the cost necessary to significantly rebalance the portfolio. In fact, remaining above the equilibrium, or over performing, while likely not feasible in efficient markets over the long run, may be a short-term goal of mutual fund managers. As a result, we expect very little incentive when performance exceeds that of the equilibrium.

In the case where the speed of adjustment, $\hat{\lambda}$, changes with the direction of the deviation from the optimum, the Asymmetric Partial Adjustment Model is more appropriate. In the asymmetric partial adjustment model, the econometric specification in (4) is modified into:

$$
y_{t}=\alpha+\theta \boldsymbol{X}_{t}+D_{1} \gamma_{1} y_{t-1}+D_{2} \gamma_{2} y_{t-1}+v_{t}
$$

$D_{1}$ in (5) is a dummy variable equal to one if the level of risk-adjusted return is above that of the previous period (and, hence, the equilibrium), and zero if not. Similarly, $D_{2}$ is an indicator equal to one if the return is below that of the previous period, and zero if not. Therefore, the asymmetric partial adjustment model in (5) estimates two separate adjustment speeds. $\gamma_{1}$ measures the speed of adjustment parameter when the level of return is above the equilibrium and $\gamma_{2}$ measures the speed when the return is below the optimum. The associated speed of adjustments can be measured by $\hat{\lambda}_{1}=1-\hat{\gamma}_{1}$ and $\hat{\lambda}_{2}=1-\hat{\gamma}_{2}$, respectively. A priori, given the competitive mutual fund environment and the lack of incentives for correcting deviations when 
performance is abnormally good, we expect managers to have an incentive to adjust as quickly as possible when fund performance is bad. Thus, we expect $\hat{\lambda}_{1}>\hat{\lambda}_{2}$.

\section{Estimation Methodology}

We apply the asymmetric partial adjustment framework in a panel data setting using a fixed effect estimation procedure. The dependent variable in our empirical framework is a riskadjusted measure of mutual fund return. In our study we compute three measures of risk-adjusted return. The first is a modified version of the ratio defined by Sharpe (1966),

$$
\operatorname{Sharpe}_{i, t}=\frac{r_{i, t}}{\sigma_{\left(r_{i, t}\right)}}
$$

which is the average return, scaled by its standard deviation. In (6), $r_{i, t}$ is the return for

mutual fund $i$ in time period $t$, and $\sigma_{\left(r_{i, t}\right)}$ is the standard deviation of the return for mutual fund $i$ at time $t$. The Sharpe ratio essentially measures the return achieved by a mutual fund per unit of risk taken. This ratio should be determined by financial market and economic conditions, and there should be an optimal or target Sharpe ratio that is achievable in the financial markets. Therefore, the partial adjust model that measures the degree to which fund managers balance the costs and benefits of rebalancing portfolios towards the optimal ratio can be appropriately measured by the asymmetric partial adjustment model. The second risk-adjusted measure of return is similar to that defined by Treynor (1966):

$$
\text { Treynor }_{i, t}=\frac{r_{i, t}}{\beta_{\left(r_{i, t}\right)}}
$$

where $r_{i, t}$ is the average return for mutual fund $i$ in time period $t$, and $\beta_{\left(r_{i, t}\right)}$ is the beta coefficient calculated using the CAPM single factor model for mutual fund $i$ at time $t$. This is 
another measure of risk-adjusted return that, unlike the Sharpe ratio, scales the fund's return by the amount of risk that that particular fund will contribute to a diversified portfolio. Again, economic conditions should dictate a long-run equilibrium level of the Treynor ratio that is attainable by investors. The third and final measure of risk-adjusted return is the alpha defined by Jensen (1968), which is the intercept term from the single factor CAPM. Alpha measures the fund's abnormal return, or the amount of return investors yield from the mutual fund manager's skill. A positive value of alpha is an indication that the manager is efficient; however, expenses and transaction costs can offset benefits attained by realizing a positive alpha.

The general econometric specification we use to estimate how quickly mutual funds adjust to their respective optimal portfolio allocations is represented by:

$$
\begin{aligned}
& \text { Sharpe }_{i, t}=\alpha_{i}+\gamma_{1} \text { High } \text { Sharpe }_{t-1}+\gamma_{12} \text { High } \times \text { Sharpe }_{t-2}+ \\
& \gamma_{2} \text { Low } \times \text { Sharpe }_{t-1}+\gamma_{22} \text { Low } \times \text { Sharpe }_{t-2}+\theta \boldsymbol{X}_{t}++v_{t} . \\
& \text { Treynor }_{i, t}=\alpha_{i}+\gamma_{1} \text { High } \times \text { Treynor }_{t-1}+\gamma_{12} \text { High } \times \text { Treynor }_{t-2}+ \\
& \gamma_{2} \text { Low } \times \text { Treynor }_{t-1}+\gamma_{22} \text { Low } \times \text { Treynor }_{t-2}+\theta \boldsymbol{X}_{t}++v_{t} . \\
& \text { Alpha }_{i, t}=\alpha_{i}+\gamma_{1} H i g h \times \text { Alpha }_{t-1}+\gamma_{12} H i g h \times \text { Alpha }_{t-2}+ \\
& \gamma_{2} \text { Low } \times \text { Alpha }_{t-1}+\gamma_{22} \text { Low } \times \text { Alpha }_{t-2}+\theta \boldsymbol{X}_{t}++v_{t} .
\end{aligned}
$$

The empirical specification in (8) - (10) is the same as that presented in (5) with the addition of a second set of asymmetric adjustment parameters that measure the degree to which the deviation from the equilibrium return is reversed by the next two periods. These adjustment parameters are estimated by the $\gamma_{12}$ and $\gamma_{22}$ parameters. These coefficients can have important 
implications with regards to the proper specification of the model. The vector of variables that determine the target or equilibrium risk-adjusted return achievable by each respective fund, $\boldsymbol{X}_{t}$, are the market Sharpe Ratio (Market Sharpe) and the average Sharpe ratio for a mutual fund within the same Lipper Classification (Classification Sharpe) as denoted by the CRSP Mutual Fund dataset for (8), the market return (market beta is unity) (Market Treynor) and the average Treynor ratio for a mutual fund within the same Lipper Classification (Classification Treynor) for (9), and the average alpha for a mutual fund within the same Lipper Classification (Classification Alpha) for (10). The Lipper Classification classifies mutual funds by the types of securities they are chartered to purchase.

As a secondary set of results, we test whether the speed of adjustment is heterogeneous among different types of mutual funds. For this purpose, we divide the sample into eight "styles", based on the Lipper Objective defined in the CRSP dataset. The eight styles consist of General Equity Funds, International Funds, International Focused Funds, Global Funds, Global Focused Funds, Sector Funds, Emerging Market Funds, and Market Index Funds. Table 1 presents the mapping of the Lipper Objectives to our eight defined styles. ${ }^{10}$

\section{The Data}

The data for this study are from the CRSP Mutual Fund dataset. Daily and monthly mutual fund returns from January 2000 through December 2013 are analyzed. Daily data are used to compute monthly and quarterly performance measures for each mutual fund, and monthly data are used to compute yearly measures. Market index returns and the U.S. risk-free are from the website of Kenneth French. The data are windsorized at the one percent level for each performance measure in question in order to reduce the influence of outliers and data errors.

\footnotetext{
${ }^{10}$ All tables and figures appear following this paper's conclusion section.
} 
Additionally, the mutual fund return data sets are merged with annual summary information from CRSP, which includes information describing the fund, including net asset value, fund family, management fees, age of the fund, fund management group, etc.

Table 2 presents the summary statistics for the monthly sample under observation for several key variables. The first column presents the summary statistics for the full 2000 to 2013 sample. The sample contains $1,885,540$ observations for approximately 22,900 equity mutual funds. The average monthly return for a fund in the sample is approximately 0.6 percent. The average monthly Sharpe ratio for the sample is 0.074 with a standard deviation of 0.226 . A positive Sharpe ratio indicates a positive relationship between risk and return, as expected. The relatively small value of the average Sharpe ratio indicates that, when computed using daily returns, daily returns are small, compared with its standard deviation. The average Treynor ratio is also positive, with an average value of 0.048 and a standard deviation of 0.416 . In addition, the average value of alpha is slightly positive, at 0.007 . Additionally, the average mutual fund in the sample has a net asset value (NAV) of $\$ 16.38$ and total net assets (TNA) of $\$ 443$ million. The average fund also charges average management fees of 0.67 percent and has an average turnover ratio of 1.67 times.

Table 2 also shows summary statistics for the subsamples of equity mutual fund styles as previously defined by their Lipper Objective. The statistics show that Emerging Market Funds yield the highest monthly returns of 1.7 percent per month, followed by Sector funds with 0.97 percent. The Market Index Funds have the lowest monthly returns of about 0.3 percent. Since Market Index Funds are more passively managed, this result is consistent with prior literature that active funds yield higher returns. Whether these higher returns are high enough to offset their expenses is another question. Indeed, Emerging Market Funds also have the highest 
management fees, while Market Focused Funds have the lowest. The summary statistics show that Market Index Funds have the lowest Sharpe ratio of 0.055 , followed by International and International Focused Funds (0.070), Sector Funds (0.072), General Equity (0.074), Global Focused Funds (0.078), Global Funds (0.083), and Emerging Markets (0.113). Similar trends are revealed for the Treynor ratios and alphas. Additionally, General Equity funds have the highest turnover, while Market Funds have the lowest. Emerging Market Funds have the highest management fees, while Market Focused Funds have the lowest. In general, the summary statistics support the idea that actively managed funds appear to be more efficient than passive funds.

\section{Partial Adjustment in Equity Mutual Funds}

The results of the fixed-effect econometric estimation of the asymmetric partial adjustment model using daily data over a one-month period are presented in Table 3. Panels A, $\mathrm{B}$, and $\mathrm{C}$ of Table 3 represent the partial adjustment estimations for the Sharpe Ratio, Treynor Ratio, and Alpha, respectively. In Panel A, the coefficient highadjust1 measures the speed of adjustment parameter when the Sharpe ratio is above the target or equilibrium ratio. A coefficient of 0.205 implies that when mutual funds experience higher than optimal performance as measured by the Sharpe ratio for one month, approximately 80 percent of the deviation is offset in the next month. Correspondingly, the coefficient lowadjust 1 of 0.0471 implies that when a mutual fund is below its equilibrium risk return tradeoff, approximately 95 percent of the deviation is offset within one month. The coefficients for the second lag of Sharpe ratio, highasjust 2 and lowasjust2, are either not statistically significant or very close to zero, implying that equilibrium is restored within the next two periods. The Market Sharpe ratio and the Lipper Classification Sharpe coefficient are both positive and significant at the five percent level, as 
expected a priori. The standard asymmetric partial adjustment model appears to fit the data well. The R-squared value of for the Sharpe ratio is 0.706 , while those of the Treynor ratio and alpha are 0.422 and 0.452 , respectively.

Panel B implies that an above equilibrium Treynor ratio will be offset by approximately 90 percent over the next period, while one below equilibrium will fully adjust (lowadjustl is insignificant). Similar interpretations apply when alpha is used as the dependent variable in Panel $\mathrm{C}$; however, lowadjust 1 is negative and significant. While this would normally violate the assumption of the partial adjustment model, it does not in this case. The negative coefficient implies that the fund completely offset the deviation and reversed its direction. In the context of mutual fund performance, this represents an underperforming fund becoming an over-performing one - a situation that any mutual fund manager would welcome.

The use of the asymmetric adjustment model makes a significant difference in terms of interpreting the overall efficiency of mutual funds. The relatively low adjustment speed when a fund is above the equilibrium value is consistent with the fact that there is no incentive for managers to adjust when the fund is outperforming and adds support for the implementation of the asymmetrical partial adjustment model. Particularly good outcomes tend to be transitory and the effects are short-lived, as the market naturally restores equilibrium. However, the relatively high adjustment speed when the performance measures are below the equilibrium value indicates that poorly performing fund managers are able and willing to adjust quickly to bring fund performance back to the equilibrium level. This is consistent with prior evidence that managers are sensitive to poor performance. Managers may perceive the costs of adjustment to be low, relative to the benefits of keeping current investors and attracting new investors through the 
realization of high relative returns. These results imply that managers are fairly efficient in that they are able to quickly offset deviations in fund performance.

\section{Heterogeneous Adjustment Across Mutual Fund Styles}

One of the benefits of actively managed mutual funds is that they allow lay investors to benefit from the information gathering and expertise of professional managers familiar with specific areas of the financial markets. However, mutual funds often have different objectives that may require gathering different types of information. Thus, there may be differences in the costs of portfolio adjustment across different fund types. As a result, the estimated speed of adjustment may be different across fund types as well. In this section, we divide the sample based on the eight previously defined styles and examine the speed of adjustment estimates across fund types. The fixed effect estimation of the empirical model is presented in Tables 4, 5, and 6.

Table 4 presents the fixed effect estimation for the asymmetric partial adjustment model across different fund types using the Sharpe ratio as the dependent variable. A major result is consistent with the full sample estimation of an asymmetric adjustment speed when the Sharpe ratio is above the equilibrium value is that relatively slower than when the Sharpe ratio is below the equilibrium value. This result is consistent across all types of equity mutual funds specified in this study. Additionally, the Market Sharpe and Classification Sharpe coefficients are consistently positive and significant across all fund types, which is consistent with a priori expectations.

More importantly, Table 4 provides further results regarding the relative efficiency of mutual funds focused on different types of securities. The highadjust 1 coefficient is highest 
(adjustment is slowest) for Emerging Market Funds at 0.33. Global, International and Sector Funds adjust more quickly. On the other hand, Market and General Equity Funds adjust the fastest with coefficients of 0.0148 and 0.1739 , respectively. In the context of mutual fund performance, this means that actively managed funds that focus on more specialized markets are able to achieve more prolonged above average performance. Similarly, the lowadjust1 coefficient (-0.11) is lowest (faster adjustment) for Emerging Market Funds and lowest (insignificant) for Market Funds. This indicates that more specialized funds are able to improve performance more quickly when the fund underperforms than market funds.

Table 5 presents the fixed effect estimation for the asymmetric partial adjustment model across different fund types with the Treynor ratio as the dependent variable. Again, we see results that are consistent with the full sample estimation of an asymmetric adjustment speed when the Treynor ratio is above the equilibrium value that is relatively lower than when the Treynor ratio is below the equilibrium value. This result is consistent across all types of equity mutual funds specified in this study. Consistent with the results in Table 4, The Market Treynor and Classification Treynor coefficients are consistently positive and significant across fund types, which is consistent with a priori expectations. Additionally, we find a similar comparison across fund types as in Table 4. When funds over perform, more specialized firms that typically charge higher fees and produce more information are able to maintain performance advantage for a longer amount of time. Similarly, when funds underperform, those specializing in specific areas are able to adjust more quickly. These results are consistent with managers at more active funds using superior information to attain better results.

Table 6 presents the fixed effect estimation for the asymmetric partial adjustment model across different fund types with alpha as the dependent variable. Again, we see results that are 
consistent with the full sample estimation, as well as those of Tables 4 and 5. In general, we find consistent results when estimating a partial adjustment model across different fund types for three different measures of risk-adjusted return. We find that mutual funds adjust more slowly when outperforming then when underperforming - a result that makes intuitive sense. When firms underperform, managers appear to quickly offset the deviation from equilibrium, indicating the costs of underperformance are high. Additionally, firms that exhibit higher returns and charge higher fees, tend to be relatively more efficient. These results are consistent with active managers that have informational advantages that allow them to not only achieve higher returns, but also do so on a more persistent basis. However, active managers seem to demand a premium for these advantages in the form of higher expenses.

\section{Time-Varying Mutual Fund Adjustment Speeds}

In the previous sections, we show evidence that mutual fund managers quickly adjust their portfolios when the portfolio is below that of the market equilibrium, and that this result is relative to the information production by different types of mutual fund managers. However, there have been significant changes in information production over the past several decades. In particular, the efficiency of information dissemination and production has significantly increased with the use of technology driving increasingly open and integrated financial markets.

Based on the fact that information has become more efficient over time, we might expect that mutual funds have become more efficient at producing information, and, thus, we should observe an increase in speed of adjustment over time. To test this hypothesis, we estimate the fixed effect asymmetric partial adjustment model from (8) for the full equity mutual fund sample

for each year. We then capture the speed of adjustment coefficients (one minus the lowadjust1 and highadjust 1 coefficients) and examine the trend from 2000 to 2012. 
Figure 1 presents the speed of adjustment estimates for the full mutual fund sample over time. The results show that the speeds of adjustment remain mostly consistent over the sample period under study. Highadjust1 is generally lower than lowadjust1, which is consistent with the benefits of active management. In addition, there also appears to be some cyclicality in the speeds of adjustment. For example, the speed of adjustment when funds underperform tends to increase when the economy is good and decline during a recession. Conversely, the speed of adjustment when funds perform well tends to decrease during good economic times and increase during a recession. Both trends are consistent with mutual fund managers being more efficient during good economic times. One explanation of this result is consistent with the availability of information about the mutual funds. When information becomes more uncertain and costly to acquire during a recession, mutual funds become less efficient.

\section{Robustness and Further Issues}

We show results using the monthly performance ratios computed using daily data. However, the daily data and short estimation window could bias the calculation of the performance measures, and, hence, the speed of adjustment estimation. In order to ensure robustness of the results presented, the frequency of the data should be expanded to include the calculation of the risk-adjusted measure of return (Sharpe ratio) over a longer time period such as 60 or 90 days worth of daily observations. In unreported regressions, the speed of adjustment estimations are conducted using daily data over a quarterly timeframe, as well as using monthly data for a yearly timeframe. The results are economically unchanged.

The dependent variables in our main partial adjustment estimation of adjustment speed are measures of risk-adjusted mutual fund returns. There are, however, several other measures that should be used in order to ensure robustness of the results presented. For example, a multi- 
factor model like that of Fama and French (1992) could be used to calculate expected returns. An advantage of these measures is that they incorporate more complex asset-pricing models into the measure of risk-adjusted return. A major obstacle in the use of other measures has been the limitation of using daily observations over a one-month period. The 21 observations available for each month does not provide enough variation for an accurate estimation of the Treynor ratio or market model expected returns. Expanding the data to include more daily observations per estimation period, or using rolling estimation windows will ensure the estimates provided are robust to the use of risk-adjusted measure of return.

Finally, the results presented in this analysis focus mostly on macroeconomic and fundtype characteristics as determining the long-run risk-adjusted fund equilibrium. By using the fixed effect methodology, we ignore the impact of any idiosyncratic, fund-specific characteristics. These characters are captured in the intercept and error terms of the models, thus we cannot examine the relationship between individual fund characteristics and speed of adjustment.

The CRSP mutual fund dataset provides fund-specific information such as information regarding management fees, manager tenure, fund age, and turnover. This data should be used to analyze the relationship between key fund-specific variables and the speed of adjustment. This will expand on the efficacy of the results of the paper, as it will provide some significant implications for mutual fund governance. In unreported regressions, we test for the potential firm-specific determinants of speed of adjustment, but have yet to find conclusive results. 


\section{Conclusion}

Mutual funds and other pooling arrangements have become increasingly important arrangements in the financial markets over several decades. The benefits of low cost diversification and the ability of lay investors to receive active, professional portfolio management has allowed many more investors to access the capital markets. The resulting increase in available capital has helped fuel the increasingly expanding financial markets. It is, therefore, important to analyze and understand how efficient mutual funds are able to allocate funds for their investors, thereby giving them the best risk-adjusted return.

The mutual fund manager plays a key role in the ability of mutual funds to allocate assets to create the most efficient portfolios. The managers are charged with achieving the highest riskadjusted level of return for their investors, given their fund's objective. Overall market fundamentals drive the equilibrium level of risk-adjusted return attainable in the financial markets. A manager's allocation decisions determine whether an individual fund will fall below or above the market equilibrium. When a fund's performance is below that of the equilibrium level, the fund manager has an incentive to rebalance the portfolio in an attempt to close the performance gap. The consequence of not re-allocating quickly enough is a flow of funds away from the fund. However, portfolio rebalancing is costly. Trading costs as well as information costs, which must be passed on to the investors, make the manager reluctant to engage in unnecessary rebalancing, especially when random price changes may offset his actions. Thus, the mutual fund manager faces a tradeoff. He or she must balance the benefits of quickly reversing poor fund performance through portfolio rebalancing with the trading and information costs required to rebalance the portfolio. As a result, mutual fund managers may only choose to partially adjust to deviations from the risk-adjusted equilibrium return. 
We apply an asymmetric partial adjustment model to a panel data set of U.S. based, equity mutual funds over the period of 2000 through 2012. We estimate the speed at which mutual funds adjust to the equilibrium risk-adjusted return as a measure of mutual fund efficiency and report several significant results. First, we show that when fund performance is below the equilibrium, the average fund offsets roughly 95 percent of the deviation within a month, compared with 80 percent when fund performance is above the equilibrium. These results imply that mutual funds appear to be relatively efficient in terms of portfolio rebalancing, as mangers appear to be willing and able to rebalance towards (or above) the equilibrium riskadjusted return. Additionally, a fast adjustment speed when funds underperform implies that managers view the cost of persistent underperformance as being high - a result that has been shown in previous literature.

Secondly, we divide the sample into eight sub-categories based on the mutual fund's style or focus. The results show that funds that focus on producing information and purchasing securities in specific markets or sectors have faster adjustment speeds than those that invest in broader categories of securities. This result is consistent with the idea that mutual fund managers are able to take advantage of the information they are paying to produce. The evidence presented supports the idea that more active managers have information advantages that help them achieve above average returns as well as more efficient portfolio rebalancing. It is also shown that investors pay a premium for this advantage in the form of higher expense ratios. Finally, by applying the partial adjustment model on the sample of mutual funds over time, we show that mutual fund managers tend to more efficiently rebalance portfolios during good economic times. This evidence implies that portfolio managers (and possibly all investors) lose some information advantages during recession. 
The results shown in this paper have significant implications for investors, mutual fund managers, and mutual funds governance. We contribute significantly to the literature by looking at the time dimension of the fund manager's rebalancing decision. The efficiency with which fund managers are able to adjust to deviations from the equilibrium risk-adjusted return may represent a benefit of active portfolio management, which has previously been left un-quantified. We show that the higher costs and turnover ratios for mutual funds that focus on more specific market segments may be offset not only by higher realized returns, but also by more efficient portfolio rebalancing. 


\section{References}

Barras, L., Scaillet, O., Wermers, R., (2010). False Discoveries in Mutual Fund Performance: Measuring luck in estimated alphas. Journal of Finance., 65 (1). 179-216.

Bollen, N.P.B., Busse, J.A., (2005_. Short-Term Persistence in Mutual Fund Performance. Review of Financial Studies, 18 (2). 569-597.

Chevalier, J., Ellison, G. Are Some Mutual Fund Managers Better Than Others? Cross-sectional Patterns in Behavior and Performance. Journal of Finance 54 (3). 875-899.

Cho, S., Shin, I., 2011. Partial Adjustment, Learning, and the Smart Money Effect in Young Funds in the Korean Marketplace. Working Paper. Chung-Ang University, August 2011.

Daniel, K., Grinblatt, M., Titman, S., Wermers, R., (1997)/ Measuring Mutual Fund Performance with Characteristic-based Benchmarks. Journal of Finance. 53 (3). 1035-1058.

Elton, E.J., Gruber, M.J., Das, S., Hlavka, M., (1993). Efficiency with Costly Information: A reinterpretation of evidence from managed portfolios. Review of Financial Studies, 6 (1). 1-22.

Fama, E.F., French, K.R., (2010). Luck Versus Skill in the Cross-section of Mutual Fund Returns. Journal of Finance, 65 (5). 1915-1947.

Ippolito, R.A., (1989). Efficiency with Costly Information: A study of mutual fund performance, 1965-1984. Quarterly Journal of Economics, 104 (1). 1-23.

Jensen, M., (1968). The Performance of Mutual Funds in the Period 1945-1964. Journal of Finance. 23. 389-416.

Kennan, J.,(1979). The Estimation of Partial Adjustment Models with Rational Expectations. Econometrica 47 (6). 1441-1455.

Kosowski, R., Timmermann, A., Wermers, R., White, H., (2006). Can Mutual Fund "Stars" Really Pick Stocks? New Evidence from a Bootstrap Analysis. Journal of Finance, 61 (6). 2551 2595.

Khorana, A., (1996). Top Management Turnover An Empirical Investigation of Mutual Fund Managers. Journal of Financial Economics, 40. 403-427.

Kothari, S.P., Warner, J.B., (2001). Evaluating Mutual Fund Performance. Journal of Finance, 56 (5). 1985-2010.

Lehmann, B.N., Modest, D.M., (1987). Mutual Fund Performance Evaluation: A comparison of benchmarks and benchmark comparisons. Journal of Finance, 42 (2). 233-265.

Sharpe, W. F., (1966). Mutual Fund Performance. Journal of Business, 39 (1). 119-138.

Sirri, E.R., Tufano, P.,(1998). Costly Search and Mutual Fund Flows. Journal of Finance, 53 (5). 1589-1622. 
Treynor, J., Mazuy, K., (1966). Can Mutual Funds Outguess the Market?. Harvard Business Review, 44, 131-136.

Volkman, D.A., (1999). Market Volatility and Perverse Timing Performance of Mutual Fund Managers. Journal of Financial Research, 22 (4). 449-470.

Wermers, R., (2000). Mutual Fund Performance: An empirical decomposition into stock-picking talent, style, transaction costs, and expenses. Journal of Finance, 55 (4). 1655-1695. 
Table 1: Style by Lipper Objective

\begin{tabular}{|c|c|c|}
\hline \multirow[t]{2}{*}{ Style } & \multicolumn{2}{|c|}{ Lipper Objective } \\
\hline & Basic Materials Funds & Natural Resources Funds \\
\hline \multirow{6}{*}{ Sector } & Consumer Goods Funds & Science \& Technology Funds \\
\hline & Consumer Services Funds & Specialty/Miscellaneous Funds \\
\hline & Financial Services Funds & Real Estate Funds \\
\hline & Gold Oriented Funds & Telecommunication Funds \\
\hline & Health/Biotechnology Funds & Utility Funds \\
\hline & Industrials Funds & \\
\hline \multirow{2}{*}{ International } & International Funds & International Small-Cap Funds \\
\hline & International Income Funds & \\
\hline \multirow{3}{*}{$\begin{array}{l}\text { International } \\
\text { Focused }\end{array}$} & International Real Estate Funds & Japanese Funds \\
\hline & China Region Funds & Pacific Ex Japan Funds \\
\hline & European Region Funds & Pacific Region Funds \\
\hline Emerging Markets & Emerging Markets Funds & Latin American Funds \\
\hline \multirow{7}{*}{ General Equity } & Equity Market Neutral Funds & Income Funds \\
\hline & Long/Short Equity Funds & Flexible Portfolio Funds \\
\hline & Flexible Income Funds & Balanced Funds \\
\hline & Growth and Income Funds & Multi-Sector Income Funds \\
\hline & Growth Funds & High Current Yield Funds \\
\hline & Mid-Cap Funds & Equity Income Funds \\
\hline & Small-cap Funds & \\
\hline \multirow{2}{*}{ Global } & Global Funds & Global Income Funds \\
\hline & Global Small-Cap Funds & \\
\hline \multirow{3}{*}{ Global Focused } & Global Financial Services Funds & $\begin{array}{c}\text { Global Natural Resources } \\
\text { Funds }\end{array}$ \\
\hline & $\begin{array}{l}\text { Global Health/Biotechnology } \\
\text { Funds }\end{array}$ & $\begin{array}{l}\text { Global Science/Technology } \\
\text { Funds }\end{array}$ \\
\hline & Global Flexible Port Funds & Global Real Estate Funds \\
\hline Market & S\&P 500 Index Objective Funds & \\
\hline
\end{tabular}


Table 2: Summary Statistics

\begin{tabular}{|c|c|c|c|c|c|c|c|c|c|}
\hline Variable & $\begin{array}{c}\text { Full } \\
\text { Sample }\end{array}$ & $\begin{array}{c}\text { Emerging } \\
\text { Markets }\end{array}$ & $\begin{array}{c}\text { General } \\
\text { Equity }\end{array}$ & Global & $\begin{array}{l}\text { Global } \\
\text { Focused }\end{array}$ & International & $\begin{array}{c}\text { International } \\
\text { Focused }\end{array}$ & Market & Sector \\
\hline \multicolumn{10}{|l|}{ Monthly Return } \\
\hline Mean & 0.589 & 1.693 & 0.496 & 0.604 & 0.650 & 0.614 & 0.929 & 0.296 & 0.972 \\
\hline Std. Dev. & 5.154 & 6.751 & 4.889 & 4.847 & 5.454 & 5.474 & 5.945 & 4.670 & 6.173 \\
\hline \multicolumn{10}{|l|}{ Sharpe Ratio } \\
\hline Mean & 0.074 & 0.113 & 0.074 & 0.083 & 0.078 & 0.070 & 0.070 & 0.055 & 0.072 \\
\hline Std. Dev. & 0.226 & 0.264 & 0.227 & 0.235 & 0.224 & 0.221 & 0.221 & 0.197 & 0.214 \\
\hline \multicolumn{10}{|l|}{ Treynor Ratio } \\
\hline Mean & 0.048 & 0.144 & 0.041 & 0.036 & 0.058 & 0.054 & 0.114 & 0.022 & 0.068 \\
\hline Std. Dev. & 0.416 & 0.565 & 0.377 & 0.512 & 0.379 & 0.517 & 0.673 & 0.234 & 0.426 \\
\hline \multicolumn{10}{|l|}{ Alpha } \\
\hline Mean & 0.007 & 0.053 & 0.003 & 0.007 & 0.007 & 0.005 & 0.026 & -0.001 & 0.025 \\
\hline Std. Dev. & 0.126 & 0.216 & 0.105 & 0.122 & 0.134 & 0.149 & 0.193 & 0.047 & 0.189 \\
\hline \multicolumn{10}{|l|}{$N A V$} \\
\hline Mean & 16.38 & 20.29 & 15.77 & 15.89 & 15.25 & 14.86 & 17.92 & 24.10 & 20.78 \\
\hline Std. Dev. & 15.45 & 15.47 & 15.77 & 10.01 & 11.36 & 9.72 & 13.17 & 27.13 & 17.72 \\
\hline \multicolumn{10}{|l|}{$T N A$} \\
\hline Mean & 443 & 543 & 431 & 462 & 438 & 496 & 257 & 2,029 & 223 \\
\hline Std. Dev. & 2,436 & 2,481 & 2,287 & 2,732 & 1,476 & 2,343 & 985 & 8,838 & 921 \\
\hline \multicolumn{10}{|l|}{ 12-1b Fees } \\
\hline Mean & 0.006 & 0.006 & 0.006 & 0.006 & 0.006 & 0.006 & 0.006 & 0.005 & 0.006 \\
\hline Std. Dev. & 0.004 & 0.004 & 0.004 & 0.003 & 0.003 & 0.004 & 0.004 & 0.003 & 0.004 \\
\hline \multicolumn{10}{|c|}{ Management Fees (\%) } \\
\hline Mean & 0.667 & 0.996 & 0.632 & 0.716 & 0.684 & 0.782 & 0.789 & 0.193 & 0.736 \\
\hline Std. Dev. & 0.320 & 0.348 & 0.310 & 0.306 & 0.314 & 0.286 & 0.315 & 0.127 & 0.302 \\
\hline \multicolumn{10}{|l|}{ Turnover } \\
\hline Mean & 1.67 & 0.87 & 1.95 & 0.88 & 0.90 & 0.85 & 1.06 & 0.11 & 1.62 \\
\hline Std. Dev. & 291.45 & 1.69 & 351.08 & 0.99 & 1.29 & 0.95 & 2.81 & 0.23 & 3.67 \\
\hline$N$ & $1,885,540$ & 40,536 & $1,303,178$ & 87,690 & 43,471 & 178,128 & 42,295 & 27,424 & 162,818 \\
\hline
\end{tabular}


Table 3: Monthly Partial Adjustment

Panel A: Dependent Variable - Sharpe

Ratio

\begin{tabular}{lrrrr}
\hline \multicolumn{1}{c}{ Variable } & Coefficient & $\begin{array}{c}\text { Std. } \\
\text { Error }\end{array}$ & $\begin{array}{c}\text { t- } \\
\text { Statistic }\end{array}$ & Prob. \\
\hline Intercept & 0.0242 & 0.0044 & 5.472 & 0.000 \\
highadjust1 & 0.2050 & 0.0296 & 6.924 & 0.000 \\
highadjust2 & 0.0004 & 0.0001 & 2.750 & 0.006 \\
lowadjust1 & 0.0471 & 0.0181 & -2.593 & 0.010 \\
lowadjust2 & 0.0000 & 0.0001 & 0.220 & 0.826 \\
Market Sharpe & 0.9104 & 0.0196 & 46.353 & 0.000 \\
Classification & & & & \\
Sharpe & 0.0185 & 0.0047 & 3.906 & 0.000 \\
R-Square & 0.706 & & & \\
No. of Funds & 22,939 & & & \\
$N$ & $1,865,715$ & & & \\
\hline
\end{tabular}

Panel B: Dependent Variable - Treynor Ratio

\begin{tabular}{lrrrr}
\hline \multicolumn{1}{c}{ Variable } & $\begin{array}{c}\text { Coefficien } \\
\mathrm{t}\end{array}$ & $\begin{array}{c}\text { Std. } \\
\text { Error }\end{array}$ & $\begin{array}{c}\mathrm{t} \text { - } \\
\text { Statistic }\end{array}$ & Prob. \\
\hline Intercept & 0.0291 & 0.0062 & 4.725 & 0.000 \\
highadjust1 & 0.1182 & 0.0306 & 3.861 & 0.000 \\
highadjust2 & 0.0000 & 0.0000 & 1.959 & 0.050 \\
lowadjust1 & -0.0094 & 0.0198 & -0.474 & 0.635 \\
lowadjust2 & 0.0000 & 0.0000 & -0.111 & 0.912 \\
Market Return & 0.0541 & 0.0012 & 46.202 & 0.000 \\
Classification & & & & \\
Treynor & 0.0001 & 0.0000 & 2.116 & 0.034 \\
R-Square & 0.422 & & & \\
No. of Funds & 22,939 & & & \\
N & $1,865,715$ & & & \\
\hline
\end{tabular}

Panel C: Dependent Variable -

Alpha

\begin{tabular}{lrrrr}
\hline \multicolumn{1}{c}{ Variable } & Coefficient & Std. & Error & t- \\
Statistic & Prob. \\
\hline Intercept & 0.0071 & 0.0002 & 32.376 & 0.000 \\
highadjust1 & 0.1169 & 0.0054 & 21.645 & 0.000 \\
highadjust2 & 0.0016 & 0.0011 & 1.481 & 0.139 \\
lowadjust1 & -0.0358 & 0.0034 & -10.526 & 0.000 \\
lowadjust2 & 0.0126 & 0.0027 & 4.609 & 0.000 \\
Classification & & & & \\
Alpha & 0.6966 & 0.0106 & 65.723 & 0.000 \\
R-Square & 0.452 & & & \\
No. of Funds & 22,939 & & & \\
$N$ & $1,866,031$ & & & \\
\hline
\end{tabular}


Table 4: Fixed Effect Speed of Adjustment Estimation: Sharpe Ratio

\begin{tabular}{|c|c|c|c|c|c|c|c|c|}
\hline Variable & $\begin{array}{c}\text { Emerging } \\
\text { Markets }\end{array}$ & $\begin{array}{c}\text { General } \\
\text { Equity }\end{array}$ & Global & Global Focused & International & $\begin{array}{c}\text { International } \\
\text { Focused } \\
\end{array}$ & Market & Sector \\
\hline \multirow{2}{*}{ Intercept } & 0.0799 & 0.0199 & 0.0405 & 0.0359 & 0.0229 & 0.0539 & 0.0020 & 0.0426 \\
\hline & 4.65 & 5.40 & 5.15 & 3.56 & 2.23 & 4.82 & 2.16 & 8.08 \\
\hline \multirow[t]{2}{*}{ highadjust1 } & 0.3304 & 0.1739 & 0.2659 & 0.1435 & 0.2720 & 0.2979 & 0.0148 & 0.2302 \\
\hline & 5.23 & 6.37 & 6.14 & 3.35 & 4.19 & 4.70 & 2.64 & 7.24 \\
\hline \multirow[t]{2}{*}{ highadjust2 } & 0.0001 & 0.0006 & 0.1026 & 0.0001 & 0.0936 & 0.2020 & -0.0025 & 0.0003 \\
\hline & 1.42 & 2.15 & 2.45 & 0.67 & 1.52 & 3.38 & -0.77 & 3.51 \\
\hline \multirow[t]{2}{*}{ lowadjust1 } & -0.1072 & -0.0325 & -0.0824 & -0.0609 & -0.0677 & -0.0410 & -0.0036 & -0.1126 \\
\hline & -1.97 & -1.87 & -2.90 & -2.05 & -1.65 & -1.08 & -1.34 & -4.67 \\
\hline \multirow[t]{2}{*}{ lowadjust 2} & -0.0878 & -0.0002 & 0.0003 & -0.1152 & 0.0010 & -0.1205 & -0.0055 & -0.0001 \\
\hline & -1.59 & -1.80 & 2.12 & -3.92 & 3.73 & -3.23 & -1.82 & -0.74 \\
\hline \multirow[t]{2}{*}{ Market Sharpe } & 0.8990 & 0.9539 & 0.8664 & 0.9042 & 0.7727 & 0.7101 & 0.0014 & 0.7113 \\
\hline & 13.55 & 58.75 & 26.49 & 22.78 & 15.14 & 13.21 & 0.11 & 27.21 \\
\hline \multirow[t]{2}{*}{ Classification Sharpe } & 0.0320 & 0.0171 & 0.0038 & 0.0184 & 0.0958 & 0.0282 & 0.9871 & 0.0224 \\
\hline & 1.60 & 2.83 & 0.58 & 2.46 & 2.85 & 1.28 & 78.62 & 1.94 \\
\hline$R$-Square & 0.579 & 0.759 & 0.605 & 0.719 & 0.661 & 0.545 & 0.994 & 0.516 \\
\hline No. of Funds & 559 & 15,893 & 1,337 & 928 & 2,212 & 603 & 284 & 2,222 \\
\hline$N$ & 40,100 & $1,289,108$ & 86,781 & 43,121 & 176,418 & 41,935 & 27,159 & 161,093 \\
\hline
\end{tabular}


Table 5: Fixed Effect Speed of Adjustment Estimation: Treynor Ratio

\begin{tabular}{|c|c|c|c|c|c|c|c|c|}
\hline Variable & $\begin{array}{c}\text { Emerging } \\
\text { Markets }\end{array}$ & $\begin{array}{l}\text { General } \\
\text { Equity }\end{array}$ & Global & $\begin{array}{c}\text { Global } \\
\text { Focused }\end{array}$ & $\begin{array}{c}\text { Internationa } \\
1\end{array}$ & $\begin{array}{l}\text { Internationa } \\
1 \text { Focused }\end{array}$ & Market & Sector \\
\hline \multirow[t]{2}{*}{ Intercept } & 0.1003 & 0.0225 & 0.0037 & 0.0282 & 0.0247 & 0.1030 & 0.0032 & 0.0534 \\
\hline & 3.26 & 4.24 & 0.33 & 2.41 & 1.25 & 4.56 & 0.80 & 6.64 \\
\hline \multirow{2}{*}{ highadjust1 } & 0.2333 & 0.0942 & 0.0973 & 0.0770 & 0.1534 & 0.1618 & -0.0138 & 0.1270 \\
\hline & 2.68 & 2.89 & 2.39 & 1.54 & 2.74 & 2.85 & -0.83 & 3.88 \\
\hline highadjust2 & 0.0047 & 0.0000 & 0.0001 & 0.0088 & 0.0002 & -0.0020 & -0.0088 & 0.0000 \\
\hline lowadjust 1 & -0.53 & -0.26 & 1.53 & 0.24 & -0.17 & -2.22 & -0.20 & -1.17 \\
\hline \multirow[t]{2}{*}{ lowadjust2 } & 0.0000 & 0.0000 & 0.0002 & -0.0005 & -0.0001 & 0.0009 & -0.0186 & 0.0001 \\
\hline & -1.01 & -0.65 & 0.64 & -6.20 & -0.38 & 4.32 & -1.33 & 2.85 \\
\hline \multirow[t]{2}{*}{ Market Return } & 0.0740 & 0.0522 & 0.0550 & 0.0562 & 0.0651 & 0.0669 & 0.0266 & 0.0470 \\
\hline & 14.14 & 53.99 & 30.62 & 30.26 & 17.03 & 15.43 & 2.64 & 30.33 \\
\hline$R$-Square & 0.431 & 0.477 & 0.304 & 0.588 & 0.406 & 0.256 & 0.965 & 0.303 \\
\hline No. of Funds & 559 & 15,893 & 1,337 & 928 & 2,212 & 603 & 284 & 2,222 \\
\hline$N$ & 40,100 & $1,289,108$ & 86,781 & 43,121 & 176,418 & 41,935 & 27,159 & 161,093 \\
\hline
\end{tabular}


Table 6: Fixed Effect Speed of Adjustment Estimation: Alpha

\begin{tabular}{|c|c|c|c|c|c|c|c|c|}
\hline Variable & $\begin{array}{l}\text { Emerging } \\
\text { Markets }\end{array}$ & $\begin{array}{l}\text { General } \\
\text { Equity }\end{array}$ & Global & $\begin{array}{l}\text { Global } \\
\text { Focused }\end{array}$ & International & $\begin{array}{l}\text { International } \\
\text { Focused }\end{array}$ & Market & Sector \\
\hline \multirow[t]{2}{*}{ Intercept } & 0.0340 & 0.0041 & 0.0094 & 0.0081 & 0.0053 & 0.0116 & 0.0027 & 0.0303 \\
\hline & 2.59 & 4.12 & 2.10 & 3.60 & 2.11 & 4.80 & 1.55 & 3.50 \\
\hline \multirow[t]{2}{*}{ highadjust1 } & 0.1389 & 0.0997 & 0.1814 & 0.0530 & 0.0740 & 0.0632 & 0.4059 & 0.1318 \\
\hline & 2.65 & 3.58 & 2.28 & 1.98 & 2.24 & 3.15 & 2.81 & 4.07 \\
\hline \multirow{2}{*}{ highadjust2 } & 0.0006 & 0.0026 & 0.0361 & 0.0104 & -0.0010 & 0.0005 & -0.0738 & 0.0613 \\
\hline & 0.95 & 0.51 & 0.85 & 0.38 & -0.17 & 0.03 & -0.83 & 1.59 \\
\hline \multirow[t]{2}{*}{ lowadjust1 } & -0.1154 & -0.0245 & -0.0874 & -0.0479 & -0.0409 & -0.0262 & -0.0786 & -0.0566 \\
\hline & -2.65 & -1.92 & -2.53 & -2.00 & -2.15 & -2.38 & -1.07 & -1.81 \\
\hline \multirow[t]{2}{*}{ lowadjust 2} & 0.0327 & 0.0167 & 0.0053 & -0.0241 & 0.0098 & -0.0170 & 0.1213 & -0.0442 \\
\hline & 0.63 & 0.91 & 0.15 & -1.20 & 0.67 & -1.50 & 1.21 & -1.75 \\
\hline \multirow[t]{2}{*}{ Classification Alpha } & 0.7327 & 0.8917 & 0.8163 & 0.9156 & 0.9286 & 0.9043 & 1.0789 & 0.4104 \\
\hline & 5.14 & 57.53 & 24.38 & 53.56 & 79.28 & 79.17 & 13.24 & 2.41 \\
\hline$R$-Square & 0.630 & 0.411 & 0.552 & 0.606 & 0.758 & 0.755 & 0.708 & 0.343 \\
\hline No. of Funds & 559 & 15,898 & 1,337 & 928 & 2,212 & 603 & 284 & 2,223 \\
\hline$N$ & 40,105 & $1,289,325$ & 86,789 & 43,136 & 176,438 & 41,945 & 27,159 & 161,134 \\
\hline
\end{tabular}




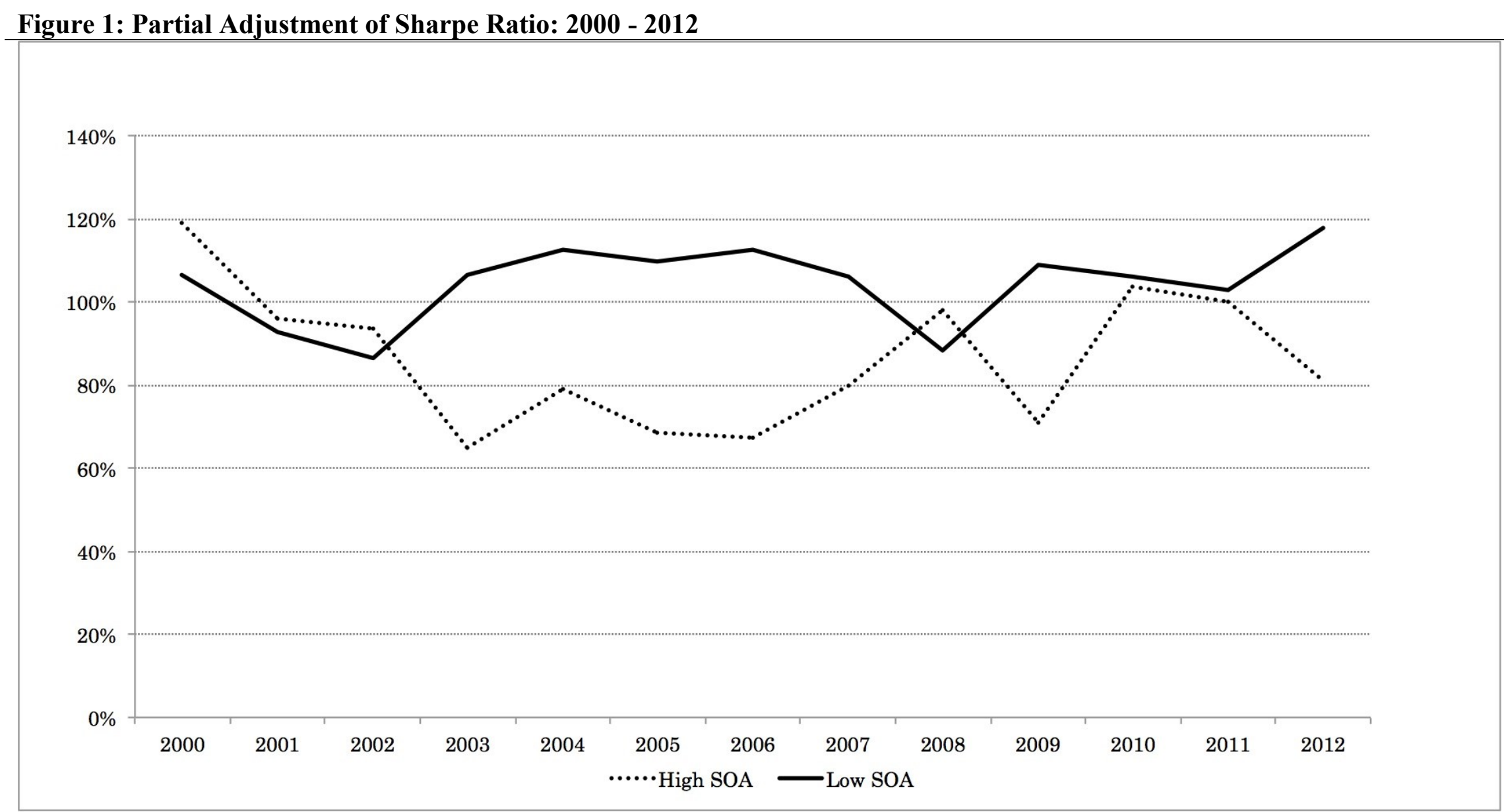

